\title{
Influence of light sources used in a street lighting for building and operating costs of lighting systems
}

\begin{abstract}
The paper deals with the design of an optimal variant of a public lighting system. Calculations are processed on a model road in urban areas. Completely new lighting system is proposed on 30-years operational period. The objective is to evaluate the benefits of the application of LED in a confrontation with conventional discharge light sources from technical and economic point of view. The decisive criterion is the economic NPV of the expenditure with regard to the amount of cost entering into the calculation.
\end{abstract}

Keywords: Design of public lighting systems, economics operation of the lighting systems, usage of LEDs

Úvod

Článek je zaměřen na srovnání celkových výdajů na výstavbu a provoz osvětlovací soustavy veřejného osvětlení (VO) s různými světelnými zdroji. Osvětlovací soustava je navržena $v$ závislosti na světelných zdrojích instalovaných ve svítidlech. Výpočty a návrhy osvětlovací soustavy jsou prováděny na modelové pozemní komunikaci délky $1 \mathrm{~km}$ $\checkmark$ městské zástavbě, kde je počítáno s výstavbou zcela nové osvětlovací soustavy. Dopravní komunikace je začleněna do skupiny světelných situací B1, (dle ČSN CEN/TR 13-201-1) a požadavků třídy osvětlení ME4b, dle ČSN EN 13-201-2. Pro návrh osvětlovací soustavy byly vybrány svítidla téhož výrobce jedné výrobní řady, kvưli možnosti objektivního hodnocení. Svítidla byla $v$ modelových prípadech osazena vysokotlakými sodíkovými výbojkami, halogenidovými výbojkami a LED diodovými moduly. V článku je srovnání, jak se promítá do počtu budovaných světelných míst na jednotkovém úseku pozemní komunikace osazení osvětlovací soustavy svítidly $s$ vypuklým (GB) a plochým difuzorem (FG). V př́ipadě svítidel $s$ LED je porovnán provoz LED modulů $s$ udržováním konstantního světelného toku po dobu života (CLO) a bez něj. Ekonomické výpočty zahrnují výdaje na výstavbu, provoz, pravidelnou údržbu a opravy po dobu provozování 30 let.

\section{Výstavba veřejného osvětlení}

Vybudování nové osvětlovací soustavy je výhodnější než rekonstrukce, která může postihovat pouze obměnu samotných svítidel. Životnost svítidel je počítána minimálně na 10 let. Výměna svítidel na stávající osvětlovací soustavě je poměrně častá a optimalizuje výdaje spojené $s$ provozem. Dojde ke zlepšení světelně technických parametrů, ačkoliv ne $v$ plném rozsahu. Je-li soustava již nevyhovující a technicky zastaralá, Je lepší přistoupit k celkové rekonstrukci osvětlovací soustavy. To $v$ sobě obnáší jak výměnu svítidel, stožárů včetně příslušenstvi (betonové základy, patky, zemniče, svorkovnice), tak i výměnu elektrifikační sítě s nově dimenzovanými rozvaděči a spínacími místy.

Střední délka životnosti žárově zinkovaných stožárů veřejného osvětlení je 30 let. $V$ prípadě dodatečné povrchové úpravy vetknuté části stožáru se životnost stožáru zvýší na 45 let.

Nová výstavba celé soustavy umožní optimální rozmístění světelných míst dle projektu zohledňující použití nových svítidel $s$ vyšší účinností a zároveň umožní přizpůsobení aktuálním potřebám komunikace. Značná počáteční investicí je vynahrazena nižšími budoucími provozními výdaji. Komplexní rekonstrukcí se docílí většího snížení instalovaného príkonu soustavy než pouhou výměnou svítidel.
Při výběru vhodného svítidla je třeba brát $v$ potaz parametry, které ovlivní do budoucna vynakládané finanční prostředky na provoz celé soustavy. $V$ prvé řadě je důležité určit charakter osvětlovaného prostoru a podle toho zvolit svítidla s patřičnou charakteristikou rozložení svítivosti. Pro osvětlování běžných komunikací se použijí svítidla se širokou charakteristikou rozložení svítivosti ve směru podélném s osou komunikace a úzkou ve směru príčném [1]. Účinnost a rozložení vyzařovaného světelného toku ovlivňuje především reflektor svítidla. Optické části moderních svítidel bývají zhotoveny z eloxovaného nebo plátovaného hliníku. Optický systém svítidla bývá uzavřen tvarovaným difuzorem (popr. refraktorem) z polykarbonátu (PC) nebo polymetylmetakrylátu (PMMA). Může být uzavřen i tvrzeným sklem, plochým nebo vypouklým. K zajištění osvětlení stejné kvantity je zapotřebí o cca $5 \div 35 \%$ větší počet svítidel s plochým sklem [1] nebo je nutné je osadit světelným zdrojem o vyšším světelném toku (a tedy i př́konu) ve srovnání se svítidlem opatřeným vypouklým krytem. Tato skutečnost navyšuje investici jak na začátku, tak během celé etapy provozování světelné soustavy. Výhodnější je použití tvarovaných vypouklých difuzorů z PC nebo PMMA. Výhodou PC je vysoká mechanická odolnost. PMMA je barevně stálé po dobu života svítidla. Pro minimalizaci výdajů na údržbu svítidel je důležitý vysoký stupeň IP optické části. Tím je zaručena dlouhodobá stálost světelných parametrů. Některá svítidla umožňuji polohování světelného zdroje $v$ reflektoru, popřípadě reflektoru vůči světelnému zdroji a tím ovlivňují fotometrii svítidla. Standardně se provádí polohování celého svítidla. Efektivně se tak využije distribuovaný světelný tok ze svítidla. Polohování svítidla umožňuje jeho montáž na dřík stožáru, čímž odpadá nutnost používání výložníků pro zajištění osvětlenosti v celé šiři pozemní komunikace.

\section{Výchozí podmínky návrhu soustavy VO}

Osvětlovací soustava je navrhována pro modelovou průtažnou směrově nerozdělenou komunikaci (obr. 1) o šírce $B=8 \mathrm{~m}$, povrch tvoří tmavý asfalt. Osvětlovací soustava je jednostranná se stožáry o jmenovité výšce $H=8 \mathrm{~m}$ bez výložníků. Vzdálenost stožárů od krajnice $C=1 \mathrm{~m}$. Rozteč stožárů $L$ je závislá na fotometrických vlastnostech zvolených svítidel, dále typu a príkonu světelných zdrojů instalovaných ve svítidlech.

Jak je uvedeno $v$ literatuře [2] pro jednostrannou osvětlovací soustavu se cloněnými svítidly platí pro závěsnou výšku vztah $H \geqslant B$ Přesah světelného středu přes krajnici a má splňovat rovnost $a \leqslant 1 / 4 H$. V případě instalace svítidel bez výložníků $(t=0)$, je přesah světelného středu přes krajnici záporný. 


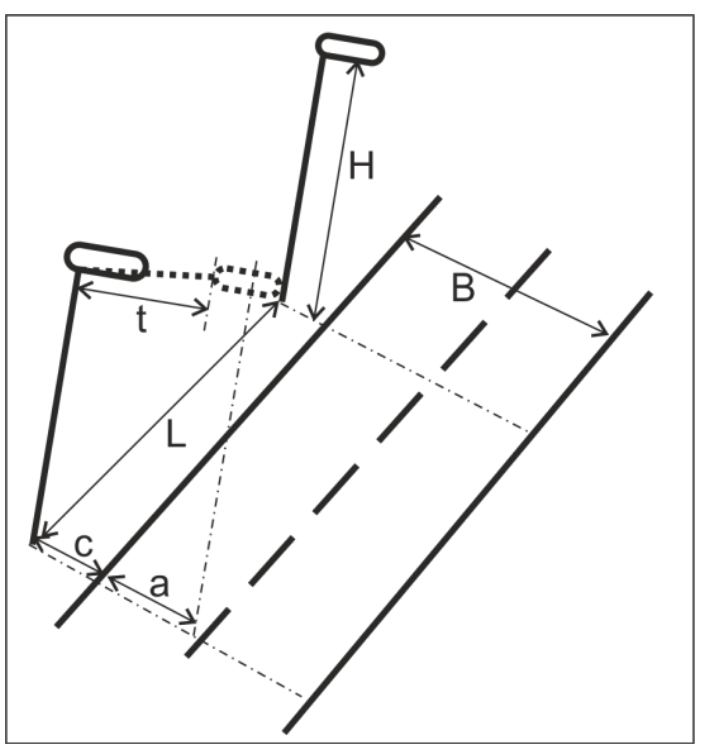

Obrázek 1 - Nákres osvětlovací soustavy

Osvětlovací soustava je plánována do městské zástavby (vysoký jas okolí) s hustotou provozu $\geqslant 7000$ automobilů denně a rychlostí omezenou na $50 \mathrm{~km} \cdot h^{-1}$. Těmto podmínkám vyhovuje třída osvětlení ME4b [3]. Parametry třídy osvětlení ME4b uvádí [4].

\section{Návrh osvětlovací soustavy}

Návrh osvětlovací soustavy je proveden se svítidly Philips Iridium ${ }^{2}$ medium, osazována výbojovými zdroji a Philips Iridium ${ }^{2}$ LED medium. Tyto modely svítidel jsou vyráběny pouze $s$ krytem optické části z rovného skla. Svítidla modelové řady Iridium téhož výrobce jsou nabízena s vypouklým difuzorem ze skla nebo polykarbonátu. Výpočty jsou prováděny se svítidly jednoho výrobce z důvodu objektivního posouzení. Vybraný výrobce nabíz svítidla shodné modelové řady jak pro výbojové světelné zdroje, tak i pro LED moduly. Svítidla opatřena krytem optické části svítidla $\mathrm{z}$ rovného skla dosahují oproti svítidlům $s$ vypouklým difuzorem menšího činitele oslnění $\mathrm{Tl}$, což je v zastavěných oblastech prínosné. Mají však menší vyzařovací úhel, což má za následek zkrácení rozteče mezi stožáry a následné prodražení výstavby $z$ důvodu nárůstu počtu světelných míst.

Vybraná svítidla jsou určena jak pro montáž na výložník, tak pro montáž na dř́k stožáru a jsou vybavena polohovacím mechanismem v rozmezí sklonu $+/-15^{\circ}$. Krytí optické části IP66 a vysoká optická účinnost umožňuje v návrhu počítat s vyšším udržovacím činitelem $\mathrm{Z}$ (MF maintenance factor). Pro komunikaci zadaných parametrů a třídy osvětlení ME $4 b$ se obvykle používají vysokotlaké sodíkové výbojky s příkonem $100 \mathrm{~W}$.

\section{Vybraná svítidla pro výpočet}

Výpočty jsou prováděny se svítidly osazená vysokotlakými sodíkovými výbojkami (HPS) $100 \mathrm{~W}$ a $150 \mathrm{~W}$, kompaktními halogenidovými výbojkami s keramickými hořáky $(\mathrm{CMH}) 90$ W. Svítidla s LED jsou ve srovnávacích výpočtech osazena moduly $85 \mathrm{~W}$ a $61 \mathrm{~W}$ s konstantním světelným tokem (CLO - Constant Light Output) po dobu života a standardními LED moduly $67 \mathrm{~W}$. Parametry světelných zdrojů uvádí tabulka 1.

Do srovnání jsou zahrnuta svítidla s rovným a vypouklým sklem pro výbojové světelné zdroje. Svítidla osazena LED moduly mají optickou část kryto rovným sklem. Vybraná svítidla pro návrh osvětlovací soustavy jsou uvedena $v$ tabulce 3 .

\begin{tabular}{|l|l|l|l|l|}
\hline Světelný zdroj & $\phi[\mathrm{klm}]$ & $\mathrm{T}_{\mathrm{c}}[\mathrm{K}]$ & $\mathrm{R}_{\mathrm{a}}[-]$ & $\mathrm{T}_{50 \%}[\mathrm{~h}]$ \\
\hline HPS 150W & 18,0 & 2000 & 25 & 36000 \\
\hline HPS 100W & 10,7 & 2000 & 25 & 36000 \\
\hline CMH 90W & 10,4 & 2800 & 66 & 30000 \\
\hline LED ECO99-CLO 85W & 10,4 & 4000 & 76 & 70000 \\
\hline LED ECO71-CLO 61W & 7,4 & 4000 & 76 & 70000 \\
\hline LED GRN88 67W & 9,2 & 4000 & 76 & 100000 \\
\hline
\end{tabular}

Tabulka 1 - Parametry světelných zdrojů

\section{Světelně technické výpočty}

U svítidel s LED s dobou života $70000 \mathrm{~h}$ až $100000 \mathrm{~h}$ (asi 17 - 25 roků provozování) se s výměnou samostatného LED modulu neuvažuje. Celé svítidlo je po této době zastaralé a opotřebované, proto se počítá s výměnou celého svítidla. I když někteří výrobci výměnu LED modulu umožňují. Doba života svítidel (pro výbojové zdroje) je optimální 10 - 20 let, u LED svítidel je to doba života světelného zdroje. $\vee$ návrhu soustavy je počíáno $s$ výměnou svítidel po 15 letech.

Výpočty osvětlovacích soustav s vybranými svítidly jsou provedeny $s$ využitím software DIALux. Veškeré světelnětechnické veličiny pro jednotlivá svítidla, které vstupují do výpočtu, jsou brány ze souborů Eulumdat. Veškerá data poskytovaná výrobcem svítidel jsou aktuální k 16. 1. 2015.

Pro správný výpočet osvětlenosti pozemní komunikace je nutné stanovit udržovací činitel dané osvětlovací soustavy. Udržovací činitel MF (viz rovnice 1) zahrnuje činitel stárnutí světelného zdroje $(L L M F)$, činitel funkční spolehlivosti světelných zdrojů ( $L S F)$ a činitel znečištění svítidel $(L M F)$.

Pro veřejné osvětlení je dle normy hodnota udržovacího činitele $M F \geqslant 0,6$ Nízký $M F$ vede při návrhu osvětlovací soustavy k předimenzování, aby byly zajištěny minimální světelné podmínky na pozemní komunikaci. Souhrnný přehled jednotlivých činitelů pro výpočet udržovacího činitele pro osvětlovací soustavy s různými světelnými zdroji uvádí tabulka 2.

$$
M F=L L M F \cdot L S F \cdot L M F
$$

U venkovního osvětlení činitel znečištění úzce souvisí se stupněm krytí (IP) svítidla, resp. jeho optické části. Pro dvouletý cyklus čištění a při středním znečištění ovzduší je pro svítidla se stupněm krytí optické části IP6X dle CIE 136:2000 činitel znečištění $L M F=0,89$.

Svítidla s vysokým stupněm krytí mají vysokou hodnotu činitele znečištění, a tudíž i udržovacího činitele. Proto nedochází při návrhu $\mathrm{k}$ předimenzování a následnému přesvětlování komunikace převážně $v$ počátečním stádiu provozu. $Z$ toho důvodu je pak i provoz soustavy se svítidly s vysokým IP hospodárnější.

\begin{tabular}{|l|l|l|l|l|}
\hline Světelný zdroj & LLMF & LSF & LMF & MF \\
\hline HPS & 0,90 & 0,96 & & 0,77 \\
\hline CMH & 0,87 & 0,99 & \multirow{4}{*}{0,89} & 0,77 \\
\hline LED-CLO & 0,99 & 1,00 & & 0,88 \\
\hline LED-standard & 0,75 & 1,00 & & 0,67 \\
\hline
\end{tabular}

Tabulka 2 - Činitelé vybraných druhů světelných zdrojů

LED svítidla s CLO technologií, která mají LLMF roven přibližně jedné, umožňují dimenzovat osvětlovací soustavu $s$ většími roztečemi mezi stožáry. Použití svítidel $s$ LEDCLO výrazně zmenšuje investice na výstavbu soustavy oproti svítidlům vybavená běžnými LED moduly, které mají vysoký LLMF. 


\section{Vypočítané hodnoty}

$\checkmark$ tabulce 3 jsou uvedeny výpočty rozteče stožárů $L$ pro vybraná svítidla s různými světelnými zdroji. Počet svítidel je určen na $1 \mathrm{~km}$ pozemní komunikace.

\begin{tabular}{|c|c|c|c|c|c|}
\hline \multicolumn{2}{|l|}{ Typ svítidla a difuzoru } & \multirow{2}{*}{$\begin{array}{l}\begin{array}{l}\text { Světelný } \\
\text { zdroj }\end{array} \\
\text { HPS } \\
150 \mathrm{~W}\end{array}$} & \multirow{2}{*}{$\begin{array}{l}P \\
{[W]} \\
164\end{array}$} & \multirow{2}{*}{$\begin{array}{l}\begin{array}{l}L \\
{[\mathrm{~m}]}\end{array} \\
35\end{array}$} & \multirow{2}{*}{$\begin{array}{l}N \quad[\mathrm{ks} \\
/ 1 \mathrm{~km}]\end{array}$} \\
\hline $\begin{array}{lll}\text { SGP } & 352 & 1 \times S O N- \\
\text { TPP } & 150 \mathrm{~W} & \text { EB FX1 } \\
\text { P1HV2 } & \\
\text { P1H }\end{array}$ & $F G$ & & & & \\
\hline $\begin{array}{l}\text { SGP } 352 \text { 1xSON- } \\
\text { TPP 100W EB FX1 } \\
\text { P1HV2 }\end{array}$ & $F G$ & $\begin{array}{l}\text { HPS } \\
100 W\end{array}$ & 112 & 26 & 38 \\
\hline $\begin{array}{l}\text { SGP } 352 \text { 1xCPO } \\
\text { 90W EB FX1 P3HV2 }\end{array}$ & $F G$ & $\begin{array}{l}\mathrm{CMH} \\
90 \mathrm{~W}\end{array}$ & 99 & 27 & 37 \\
\hline $\begin{array}{l}\text { SGS } 254 \text { GB } \\
\text { 1xSON-TPP 150W } \\
\text { CP P2 }\end{array}$ & GB & $\begin{array}{l}\text { HPS } \\
150 W\end{array}$ & 164 & 42 & 24 \\
\hline $\begin{array}{l}\text { SGS } 253 \text { GB } \\
1 \times S O N-T P P 100 W \\
\text { CR P3 }\end{array}$ & GB & $\begin{array}{l}\text { HPS } \\
100 W\end{array}$ & 112 & 32 & 31 \\
\hline $\begin{array}{l}\text { SGS } 253 \text { GB } \\
1 \times C P O 90 W \text { EB OC } \\
\text { P3 }\end{array}$ & GB & $\begin{array}{l}\text { CMH } \\
90 \mathrm{~W}\end{array}$ & 99 & 28 & 36 \\
\hline $\begin{array}{l}\text { BGP352 T15 } \\
\text { 1xECO99-3S/740 } \\
\text { DW }\end{array}$ & $F G$ & $\begin{array}{l}\text { LED- } \\
\text { CLO } \\
85 \mathrm{~W}\end{array}$ & 85 & 41 & 24 \\
\hline $\begin{array}{l}\text { BGP352 T15 } \\
\text { 1xECO71-3S/740 } \\
\text { DW }\end{array}$ & $F G$ & $\begin{array}{l}\text { LED- } \\
\text { CLO } \\
61 \mathrm{~W}\end{array}$ & 61 & 31 & 32 \\
\hline $\begin{array}{l}\text { BGP352 T15 } \\
\text { 1xGRN88-3S/740 } \\
\text { DW }\end{array}$ & $F G$ & LED $67 \mathrm{~W}$ & 67 & 28 & 35 \\
\hline
\end{tabular}

$\mathrm{FG}=$ rovné sklo (flat glass) | GB=vypouklé sklo (glass bowl)

Tabulka 3 - Parametry použitých svítidel

\section{Vstupy pro ekonomické výpočty}

Doba provozování veřejného osvětlení ročně je počítána na 4000 h, což odpovídá průměru v ČR. Do výpočtu energii vstupují jen variabilní náklady. Je počítáno s cenou 2,10 Kč za $1 \mathrm{kWh}$. Ve výpočtech je zahrnuta tvorba fondu oprav. Roční př́spěvek do fondu oprav je $3 \%$ z pořizovací ceny osvětlovací soustavy.

Úkony údržby byly stanoveny na základě stupně krytí svítidel a užitých světelných zdrojů dle standardů CIE. $S$ čištěním svítidel se počítá každé 2 roky a s výměnou výbojových zdrojů plošně každé 4 roky. $V$ prípadě svítidel se světelnými diodami se shromadnou výměnou LED modulů nepočíá. Střední doba života led modulů nepřekročí plánovanou dobu provozu svítidel 15 let. Provoz celé osvětlovací soustavy je počítán na dobu 30 let.

\section{Provozní měrné výdaje}

Provozní výdaje jsou vztaženy k době provozování 1 rok a surčitou pravidelností se opakují po celý život provozovaného zařízení. Jsou to roční výdaje na spotřebovanou elektrickou energii $C_{E}$, roční výdaje na výměnu světelných zdrojů (zprůměrováno) $C_{Z}$, roční výdaje na čištění svítidel (zprůměrováno) $C_{M}$.

$$
C_{E}=N \cdot P_{c} \cdot t_{r} \cdot C_{e l}
$$

kde: $N$ je počet svítidel soustavy (v úseku $1 \mathrm{~km}$ ) [ks], $P_{C}$ je př́kon světelného zdroje včetně ztrát $v$ předřadníku $[k W], t_{r}$ je roční doba provozu soustavy $[h], C_{e l}$ je cena elektrické energie, $1 \mathrm{kWh}[K \check{c}]$.

$$
C_{Z}=\frac{N}{T_{V}} \cdot\left(C_{z d}+C_{v}\right)
$$

Kde: $T_{V}$ je perioda skupinové výměny zdrojů $\left[\right.$ rok], $C_{z d}$ je cena světelného zdroje $[K c ̌], C_{V}$ je cena práce za výměnu světelného zdroje [Kč]

$$
C_{M}=\frac{N}{T_{m}} \cdot C_{m}
$$

Kde: $\mathrm{C}_{\mathrm{m}}$ jsou výdaje na čištění svítidla (včetně práce) [Kč], $T_{m}$ je perioda čištění svítidel [rok]

Celkové roční výdaje na provoz soustavy $C_{C}$ se vypočítaji $z$ rovnice $(5)$

$$
C_{C}=C_{E}+C_{Z}+C_{M}+C_{O}
$$

Kde: $C_{O}$ jsou roční výdaje do fondu oprav osvětlovací soustavy [Kč].

\section{Výpočet NPV}

Celková doba provozování osvětlovací soustavy je 30 let. Rozhodujícím ekonomickým kritériem je NPV (výdajů). Diskontní sazba pro výpočet NPV je $2 \%$. Výpočet je upraven o inflaci. Je počítáno s roční mírou inflace 3\%.

$$
N P V=\sum_{t=0}^{T} C F i_{t} \cdot(1+r)^{-t}
$$

Kde: $T$ je doba provozování / života [rok], $t$ je dané časové období, $C F i_{t}$ je Cash Flow daného období upravené o inflaci $[K c ̌]$ a $r$ je diskont.

Cash Flow daného období upravené o inflaci je vypočítáno z následující rovnice.

$$
C F_{t}=P \text { ř́́jmy } y_{t}-\text { ýdaje }_{t} ; P \text { ř́́jmy } y_{t}=0
$$

Provoz soustav VO, které jsou majetkem obcí, je hrazen $z$ veřejných financí. Provozování VO je neplacená služba veřejnosti, na kterou neexistuje právní nárok. Služba je poskytována všem občanům bezplatně a nelze očekávat z provozování této služby príijem. Pro provozovatele (obec) je důležité vynakládat za provoz a údržbu VO finanční prostředky s maximální efektivitou.

$$
C F i_{t}=C F_{t} \cdot(1+i)^{t}
$$

Kde: $C F_{t}$ je Cash Flow daného období [Kč], i je roční míra inflace.

Dosazením rovnice (8) do rovnice (6) dostaneme výsledný vzorec (9) pro výpočet NPV jako sumu diskontovaných CF jednotlivých období upravených o roční míru inflace.

$$
N P V=\sum_{t=0}^{T} C F_{t} \cdot\left(\frac{1+i}{1+r}\right)^{t}=\min
$$

\section{Výsledky}

Po provedených světelně technických výpočtech se svítidly osazenými různými světelnými zdroji bylo provedeno porovnání investičních a provozních výdajů. Výdaje pro jednotlivé navrhované varianty osvětlovacích soustav jsou shrnuty $v$ tabulce 4 .

Průměrné rozdělení výdajů na vybudování soustavy veřejného osvětlení uvádí graf 1 . Nejvyšší podíl na celkové vyšší pořizovacích výdajù osvětlovací soustavy VO mají výkopové zemní a stavební práce. Proto počet budovaných 
světelných míst výrazně ovlivňuje počáteční investici a tudíž i výši výdajového NPV.

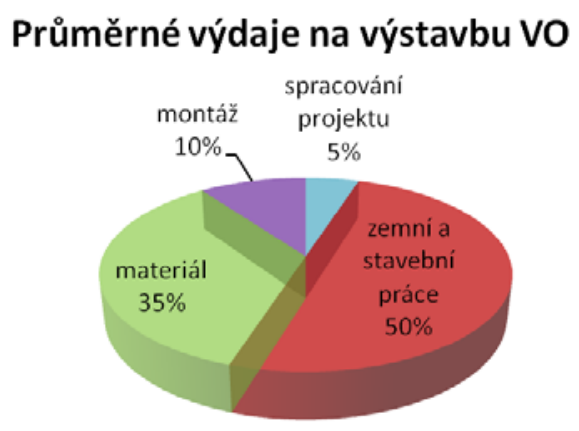

Graf 1 - Rozdělení dílčích výdajů na výstavbu osvětlovací soustavy

\begin{tabular}{|c|c|c|c|c|c|}
\hline 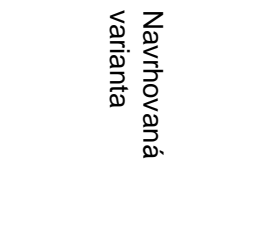 & 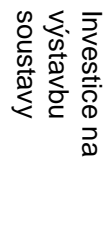 & 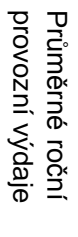 & 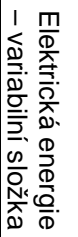 & 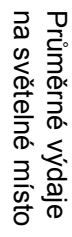 & 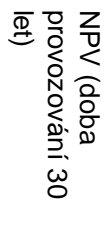 \\
\hline HPS 100W & 1957,6 & 45,8 & 29,2 & 1,5 & 3683,6 \\
\hline HPS 150W & 1811,2 & 45,8 & 33,1 & 1,9 & 3547,5 \\
\hline CMH 90W & 2096,9 & 46,9 & 29,9 & 1,3 & 3938,3 \\
\hline HPS 100W (FG) & 2104,2 & 55,3 & 35,8 & 1,5 & 4193,1 \\
\hline HPS 150W (FG) & 1915,9 & 56,3 & 40,0 & 1,9 & 4001,2 \\
\hline CMH 90W (FG) & 2118,8 & 59,2 & 30,8 & 1,6 & 4320,0 \\
\hline LED ECO99 (CLO) & 2081,3 & 34,5 & 17,1 & 1,4 & 3716,9 \\
\hline LED ECO71 (CLO) & 2338,9 & 38,1 & 16,4 & 1,2 & 4236,3 \\
\hline LED GRN88 & 2435,5 & 43,1 & 19,7 & 1,2 & 4558,6 \\
\hline
\end{tabular}

Tabulka 4 - Přehled výdajů osvětlovacích soustav osazených svítidly s vybranými světelnými zdroji

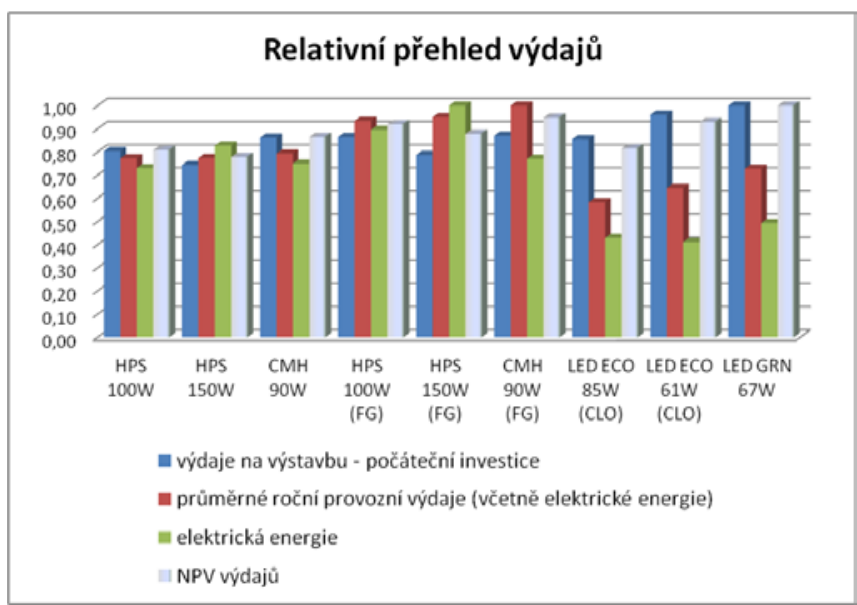

Graf 2 - Srovnání dílčích výdajů všech navrhovaných soustav

Z grafu 3 je patrné, že nejvhodnější technickoekonomické řešení je použití svítidel s vypouklým difuzorem, v prípadě výbojových zdrojů a pro prípad svítidel $s$ LED je jednoznačně výhodnější užití LED modulů s CLO technologií o vyšším príkonu.
Podle grafu 3 vyplývá, že nejnižší NPV výdajů má varianta s HPS $150 \mathrm{~W}$. To je zapříčiněno nejnižšími investičními výdaji na pořízení soustavy. Při pohledu na dílčí výdaje (graf 2) jsou varianty s HPS 150 W energeticky nejnáročnější.

V grafu 3 jsou zobrazeny celkové kumulované výdaje během trícetileté doby provozování.

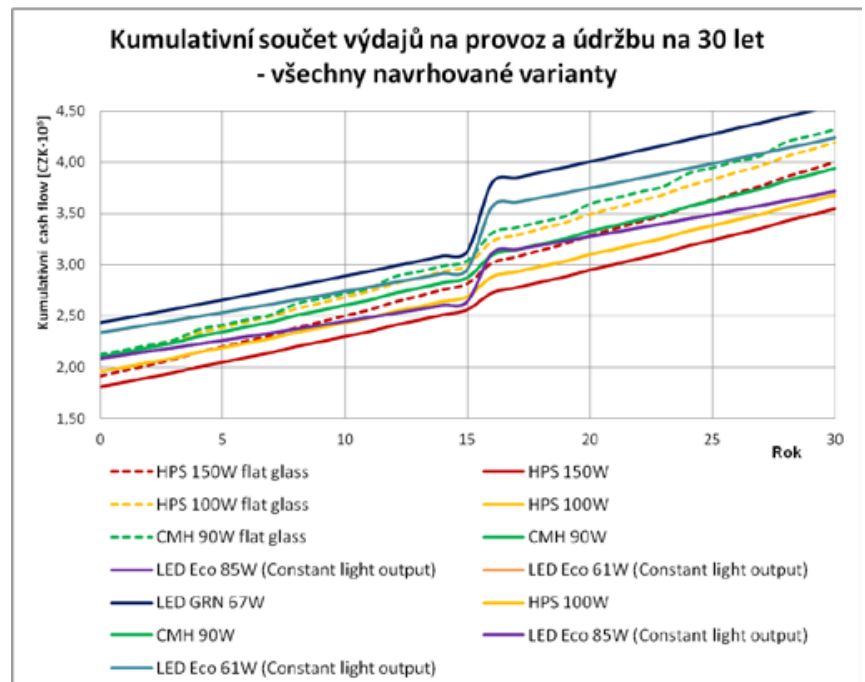

Graf 3 - Srovnání kumulativního součtu NPV všech navrhovaných osvětlovacích soustav za dobu provozování 30 let

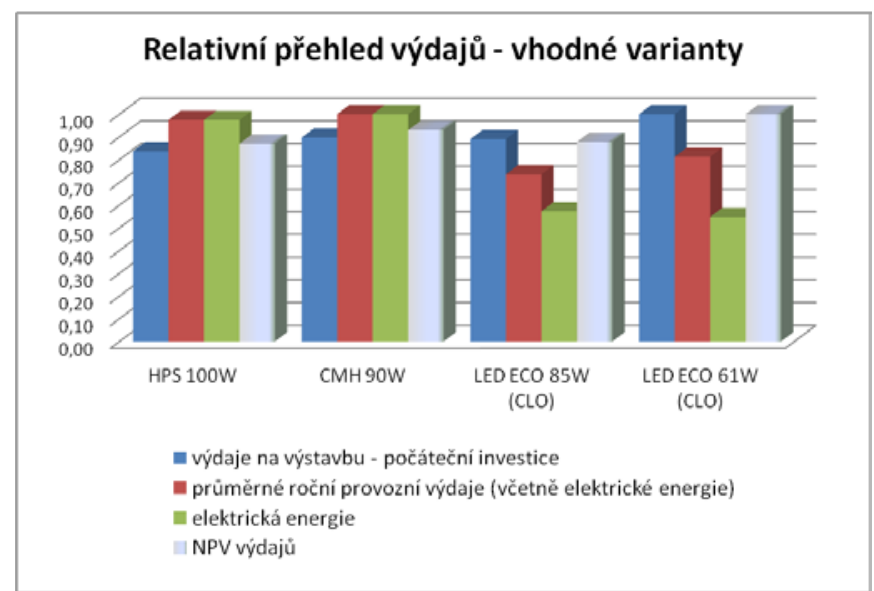

Graf 4 - Srovnání dílčích výdajů variant osvětlovacích soustav vhodných pro realizaci

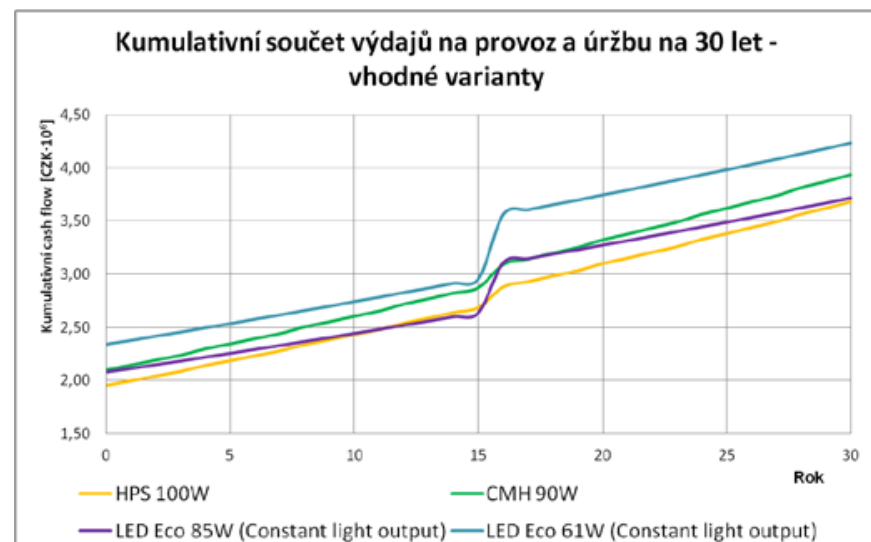

Graf 5 - Srovnání kumulativního součtu NPV osvětlovacích soustav vhodných $\mathrm{k}$ realizaci za dobu provozování 30 let 
V detailnějším pohledu z grafu 4 a grafu 5 vyplývá, že nejvhodnější technicko-ekonomické řešení pro zajištění normou stanovených parametrů na modelové pozemní komunikaci je použití svítidel osazených HPS 100 W nebo LED (CLO) moduly $85 \mathrm{~W}$.

\section{Závěr}

Nejoptimálnější variantou osvětlovací soustavy pro osvětlení pozemní komunikace $v$ městské zástavbě začleněnou do třídy osvětlení ME4b je soustava osazena svítidly s LED moduly $85 \mathrm{~W}$ s technologií CLO - Constant Light Output. Oproti soustavě se svítidly osazenými vysokotlakými sodíkovými výbojkami $100 \mathrm{~W}$ má vyšší počáteční investici na výstavbu, ale její provoz je méně nákladný. Světelný tok vysokotlaké výbojky $100 \mathrm{~W}$ a LED $85 \mathrm{~W}$ je srovnatelný (tabulka 1 ). U soustavy s LED $85 \mathrm{~W}$ je zapotřebí vybudovat méně světelných míst (tabulka 2) a v průběhu provozování odpadá plošná výměna světelných zdrojů.

Navrhovaná soustava se svítidly osazená LED moduly s př́konem $85 \mathrm{~W}$ má o $5 \%$ vyšší investiční výdaje na výstavbu ve srovnání se soustavou osazenou svítidly pro vysokotlaké sodíkové výbojky $100 \mathrm{~W}$. Celkové průměrné roční provozní výdaje osvětlovací soustavy s LED svítidly jsou o $20 \%$ nižší oproti výbojkovým svítidlům. Výdaje na spotřebovanou elektrickou energii za rok jsou u osvětlovací soustavy sLED o $30 \%$ nižší než u soustavy s vysokotlakými sodíkovými výbojkami.

Rozdíl výše investičních výdajů na pořízení navrhované osvětlovací soustavy VO se svítidly pro HPS $100 \mathrm{~W}$ a LED (CLO) $85 \mathrm{~W}$ svítidly činí 120000 Kč na $1 \mathrm{~km}$ budované osvětlovací soustavy. $V$ případě průměrných ročních výdajů na provoz soustavy VO je rozdíl přibližně 12000 Kč. Předpokládaná doba provozování osvětlovací soustavy je třicet let. Relativní spotřeba energie $v$ tomto časovém horizontu dosáhne částky $360000 \mathrm{Kč}$. NPV po dobu provozování (30 let) je u obou zmiňovaných variant přibližně shodné.

Výhodou LED oproti sodíkovým výbojkám je vyšší index podání barev $R_{a}$ a vyšší teplota chromatičnosti $T_{c}$ (tabulka 1). Vyšší index podání barev je vhodný především do městských oblastí, center, kde přispívá spolu s vyšší teplotou chromatičnosti $\mathrm{k}$ lepší zrakové pohodě účastníků silničního provozu.

Vyšší investice na pořízení osvětlení soustavy s LED 85W (CLO) a nižší provozní výdaje se vyrovnají osvětlovací soustavě osazené vysokotlakými sodíkovými výbojkami $100 \mathrm{~W}$ po 12 letech provozu. Po 12 letech provozu je osvětlovací systém osazen LED svítidly více ekonomicky efektivnější. Zlepšení komfortu účastníkům silničního provozu vlivem vyššího indexu podání barev je okamžitým prínosem LED osvětlovací soustavy.

\section{REFERENCES}

[1] Sokanský, K. a kolektiv. Metodické pokyny pro obnovu, provoz a údržbu veřejného osvětlení. Ostrava: VŠB-TU, 2008

[2] Habel, J. Světelná technika. Praha: ČVUT, 1981

[3] ČSN CEN/TR 13 201-1 Osvětlení pozemních komunikací Část 1: Výběr tríídy osvětlení.

[4] ČSN EN 13 201-2 Osvětlení pozemních komunikací - Část 2: Požadavky

[5] Šuchmann, K. Ekonomie osvětlovacích soustav. Kurs osvětlovací techniky IX - základy osvětlování I. díl. Ostrava: ČSO RS, 1994

Authors: Ing. Theodor Terrich, České vysoké učení technické v Praze, Fakulta elektrotechnická, Technická 2, 16627 PrahaDejvice, Czech Republic, e-mail: territhe@fel.cvut.cz 